ROCZNIKI HUMANISTYCZNE

Volume 67, issue $2-2019$

SELECTED PAPERS IN ENGLISH

DOI: http://dx.doi.org/10.18290/rh.2019.68.2-2en

MIROSŁAWA HANUSIEWICZ-LAVALLEE

\title{
ECHOES OF THE 1580 JESUIT MISSION TO ENGLAND IN EARLY MODERN POLAND
}

At the beginning of 1580, William Allen, one of the most influential English religious exiles, and later a cardinal, after long efforts finally persuaded Everard Mercurian, the Superior General of the Society of Jesus, and Pope Gregory XIII to send a Jesuit mission to England. Allen had treated the work on the re-Catholicization of his homeland as his own special and personal vocation. The College in Douai that he had established, and the Seminary that was part of it, went on to educate several hundred priests between 1568 and 1603; fifty-two of them started their missionary work in England before 1578. By the end of Elizabeth I's reign, the number of those English missionaries from Douai had grown to four hundred and thirty-eight. Beginning with the execution of Rev. Cuthbert Mayne's in 1577, over the next decades one hundred missionaries died as martyrs. ${ }^{1}$

For a long time Father Mercurian was unwilling to establish any mission realizing that the Jesuits' endeavour would be viewed as purely political (especially in the context of the financial and political support offered by the Pope for the ongoing Second Desmond Rebellion, in which Nicholas Sanders played a significant role), and therefore would expose the missionaries to even greater dangers than those the diocesan priests had to face. Although William Allen hoped that the Jesuits would undertake evangelization among dissenters and would enter debates with Anglican theologians, Mercurian only agreed to their conducting services among Catholics; he advised great

Prof. Dr. hab. MirosŁawa Hanusiewicz-Lavallee - John Paul II Catholic University of Lublin, Institute of Polish Studies, Department of the History of Old Polish Literature; address for correspondence: Al. Racławickie 14, 20-950 Lublin; e-mail: mirhanus@kul.lublin.pl.

The Polish version of the article was published in Roczniki Humanistyczne 61 (2013), issue 2.

${ }^{1}$ James V. Holleran, A Jesuit Challenge. Edmund Campion's Debates at the Tower of London in 1581 (New York: Fordham University Press, 1999), 13-15. 
caution and ordered to avoid all immediate controversies as far as the missionaries were not forced into them by external circumstances. Among the members of the fourteen-person mission that finally left Rome on 18 April 1580 there were only three Jesuits. The group was headed by Robert Persons, and one of his closest associates Edmund Campion, the future saint who had been summoned a few days before from Prague. Also, setting off to England with them, was Brother Ralph Emmerson. Campion himself, as his letters show, yielded to the decisions made by his superiors unenthusiastically; while in Rheims he wrote to Allen, and not without a protest, that in Prague he was very useful, and that in addition he was involved in evangelizing heretics there. ${ }^{2}$

At the beginning of 1580, hopes were growing in Rome that the efforts made by young Francis de Valois, Duke of Anjou, who for several months had been courting the ageing Queen Elizabeth and had seemed to have won her affection, would end with success. It seemed therefore obvious that one of the political consequences of such a marriage would be at least a softening of the policy towards the English Catholics and the possibile abandonment of the repressions. It cannot be excluded that such hopes and expectations motivated Mercurian's ultimate approval for forming the Jesuit mission to England, and this assumption seems to be supported by the fact that the missionaries made no attempts to conceal their journey or act as part of a conspiracy; on the contrary, on their way they preached sermons (such as in Bologna), and when they were passing Geneva they even visited Théodore de Bèze and demanded a public theological debate. However, before they reached England in June 1580, the fiasco of the French plans and the failure of the Duke's flirtations, which were strongly opposed by Elizabeth's advisers, was obvious. ${ }^{3}$ The wellknown poem by the Queen On Monsieur's Departure written a few months later symbolically sealed her own fate and both the Duke' $s$ and the French faction's political aspirations. Thus, hopes for a restoring of religious tolerance and for a softening of the policies against Catholics turned out to be in vain. When the missionaries finally crossed the English Channel and landed in various English ports in small groups, their arrival in England was already no secret and a hunt for them started immediately.

\footnotetext{
${ }^{2}$ Thomas M. McCoog, “'Playing the Champion': The Role of Disputation in the Jesuit Mission", in The Reckoned Expense: Edmund Campion and the Early English Jesuits: Essays in Celebration of the First Century of Campion Hall, ed. Thomas M. McCoog (Oxford: Boydell \& Brewer, 1996), 125-127.

${ }^{3}$ Thomas M. McCoog, "The English Jesuit Mission and the French Match, 1579-1581," The Catholic Historical Review 87 (2001), No. 2: 185-213.
} 
Robert Persons and Edmund Campion were the most important figures on this mission. They received support from magnates such as George Gilbert, which was essential not only for practical reasons, but also because of various dissonances between the missionaries and the clergymen who had been working in England since the time of Mary Tudor's reign. The arrival of the Jesuits had disturbed the status quo, most notably, among other things, with respect to the important issue of the participation of Catholics in Protestant services. Copies of Rev. Alan Langdale's brochure on the subject had been circulated among the worshippers, where he persuaded the readers that, in certain defined circumstances, such participation was possible and acceptable. However, in July 1580, during the so-called synod at Southwark, it was determined - to a large degree as a result of Persons' persuasion - that the presence of Catholics in Anglican churches would amount to an act of apostasy. Persons' first work published in the same year in London (A Brief Discourse contayning certayne reasons why Catholiques refuse to goe to Church) was an exposition of this attitude. The uncompromising nature of this standpoint inevitably exposed the faithful to serious repressions. ${ }^{4}$

Although the missionaries' work became clandestine, their activities had a very wide range of impacts, mainly thanks to the use of the printed word. When Campion made his missionary journeys in the provinces, Persons established an illegal "flying" print shop (Stephen Brinkley's Press), where he published his first book, followed by Brief Censure (1581) and A Discoverie of I. Nicols Minister, Misreported a Jesuite (1581); moreover, Campion's personal apology of Catholicism, or the letter The Challenge to the Privy Council was printed there, as well as Rationes decem (June 1581), containing elements of direct attack against the English Church. Several hundred copies of the latter work were scattered in the vicinity of the church in Oxford, which caused an understandable commotion and resulted in an intensified search for Campion. As a consequence, by July of that year, he had been captured and sent to the Tower of London. Persons at first fled to Sussex, and then to Rouen where he continued his printing work and where, by the end of 1581, he published the dramatic report on the persecutions of English Catholics, De persecutione Anglicana. ${ }^{5}$ By that time many other members of

\footnotetext{
${ }^{4}$ Peter Milward, Religious Controversies of the Elizabethan Age: A Survey of Printed Sources (Lincoln: Scolar Press, 1977), 51; Bernard BASSET, The English Jesuits from Campion to Martindale (Gloucester: Gracewing Publishing, 2004), 16-18.

${ }^{5}$ De persecutione Anglicana epistola, qua explicantur afflictiones, aerumna, [et] calamitates gravissimae, cruciatus etiam [et] tormenta [et] acerbissima martyria, quae Catholici nunc Angli ob fidem patiuntur ([Rouen], 1581).
} 
the mission were already imprisoned, among them Ralph Sherwin who had been arrested in November 1580, and the young Alexander Briant, captured in April 1581. It was only they, together with Edmund Campion, who were accused of high treason and died a martyr's death on the $1^{\text {st }}$ of December of the same year.

In far-away Poland-Lithuania Persons' epistolary report, containing the information about the tragic fate of the mission, was published in Polish almost immediately after it had been printed in Latin and simultaneously with translations into the other important vernacular languages (including English, French, Italian and German). ${ }^{6}$ It was coupled with an extensive and original foreword (Przedmowa ttumaczowa czytelnikowi potrzebna [The Translator's Foreword Necessary for the Reader]) and a translationclosing the whole book - of Chapter Eight of De Ecclesiae catholicae unitate by Saint Cyprian of Carthage. ${ }^{7}$ These elements added by the Polish translator emphasized and developed the issue of the theological meaning of martyrdom, transfered the story of the persecutions of English Catholics and of the torment of the Jesuit missionaries to the level of a more general reflection (and, at the same time, of a controversy that was topical at that time) on true and false martyrs, a controversy that was started in the Polish writings of Cyprian Bazylik and his work Historyja o srogim prześladowaniu Kościola Bożego - The Story of the Cruel Persecution of God's Church (Brześć Litewski, 1567), and next continued mostly by Piotr Skarga. Polish translation of De persecutione Anglicana was published anonymously under the title Okrucieństwo kacyrskie przeciw katolikom w Anglijej [The Heretics' Cruelty Against Catholics in England] and it is difficult to guess who could have been its author. However, in the circle of "suspects" there are two fig-

\footnotetext{
${ }^{6}$ See: Okrucieństwo kacyrskie przeciw katolikom w Anglijej, krótko przez jednego tegoż narodu opisane, a na polski język przetożone [The Heretics' Cruelty Against Catholics in England, Briefly Described By One of That Nation, And Translated Into Polish] (Poznań: [J. Wolbram], 1572). See editions and translations listed in The Contemporary Printed Literature of the English Counter-Reformation Between 1558-1640, ed. A.F. Allison and D.M. Rogers (Aldershot: Routledge, 1989-1994), vol. I, items 874-884. The list does not include the Polish one. For more about this Polish translation see: M. Hanusiewicz-Lavallee, “'Okrucieństwo kacyrskie przeciwko katolikom w Anglijej' czyli polski głos w sporze o męczeństwo ['The Heretics' Cruelty Against Catholics in England' Or a Polish Voice In the Dispute About Martyrdom]," Odrodzenie i Reformacja w Polsce 56 (2012): 37-60.

${ }^{7}$ This translation has not been included into otherwise very valuable bibliography by Janina Czerniatowicz and Czesław Mazur, Recepcja antyku chrześcijańskiego w Polsce. Materialy bibliograficzne [Reception of Christian Antiquity in Poland. Bibliographical Materials], vol. I XVI-XVIII wiek [1 $16^{\text {th- }} 18^{\text {th }}$ Century], Part 1: Autorzy i teksty [Authors and Texts] (Lublin: Towarzystwo Naukowe KUL, 1978), 43-44.
} 
ures: Hieronim Powodowski, a priest and religious writer closely connected with both the Poznań Jesuits and with Wolrab's press where the work was printed, and Jan Konarski, the rector of the Jesuit College in Poznań, whoas we know from other sources - is attributed the authorship of the translation of St. Cyprian's treatise, lost today. ${ }^{8}$ The political purport of the foreword, condemning the persecutions of English Catholics, criticizing the tolerant regulations of the Warsaw Confederation, as well as justifying the first displays of persecutions of Protestants in Poland and warning against their seizing power in the country, is completely in keeping with Powodowski's program that he carried out as a writer. ${ }^{9}$

It is Okrucienstwo kacyrskie that, for the first time, presented the figure of Edmund Campion and the figures of his companions to Polish readers. In the edition of De persecutione Anglicana published in 1582 (containing the second version of Persons' account) there appeared descriptions of the capture and the torture, information about Campion's disputations in the Tower of London, the story of the trial and martyrdom, including Ralph Sherwin's execution and nearly all the vita, and finally a description of Alexander Briant's execution, supplemented with the letter that he had written from prison to the Fathers of the Society of Jesus, in which he expressed his wish to enter the Jesuit Order. These descriptions are even briefer than the underlying account carried in the hagiographic-martyrological tradition (probably coming from Thomas Alfield and his A True Report of the Death and Martyrdome of M. Campion Jesuite and Preiste, and M. Sherwin, and M. Bryan preistes, at Tiborne [...] London 1582) that was later used in the fundamental compilation Concertatio Ecclesiae Catholicae in Anglia, first published by John Fenn and John Gibson in Trier in 1583, and then expanded upon and published again by John Brigdewater. Some elements of the narrative, however, are identical, which indicates an interpenetration of threads and motifs, coming nevertheless - as may be presumed - from a variety of sources, and illustrates the process of forming the tradition. ${ }^{10}$

\footnotetext{
${ }^{8}$ See Zofia Skorupska, “Konarski Jan,” in: Polski Stownik Biograficzny, vol. 13, ed. Emanuel Rostworowski (Kraków: Zakład Narodowy im. Ossolińskich - Wydawnictwo Polskiej Akademii Nauk, 1967-1968), 463-464; Ludwik PIECHNIK, “Działalność jezuitów na polu szkolnictwa w Poznaniu w XVI wieku”, Nasza Przeszłość 30 (1969): 188-189, 196. The other excerpt of this lost translation was added to the edition of Jan Konarski's sermon: Kazanie, które miat X. Jan Conarius [...] w kościele tumskim poznańskim przy pogrzebie [...] Stanisława Sobockiego, ed. Piotr Lilio (Poznań: Jan Wolrab, 1590), fol. C iij r. - C iijj v.

${ }^{9}$ Cf. Mieczysław Korolko, "Poglądy polityczne i społeczne Hieronima Powodowskiego [Hieronim Powodowski's Political and Social Views]", Odrodzenie i Reformacja w Polsce 12 (1967): 87-97.

${ }^{10}$ Here is a very characteristic example taken from the description of Alexander Briant: “[...]
} 
Persons' account was spread throughout the Jesuit provinces and - as Thomas McCoog states - served to show among other things the Society's political aims and supported the collection of funds to aid Catholics in England. ${ }^{11}$ More than likely the book was used for a similar purpose in Poland. A letter written on the $31^{\text {st }}$ of March 1583 by the city councillors of Elblag to Queen Elizabeth I contains a mention that might refer to De persecutione Anglicana (or even its translation); the letter informs the English monarch that "the Papal legate, who is much at our King's court, is circulating letters of certain religious or priests of the Society of Jesus, complaining that they are most cruelly imprisoned in Your Majesty's realm, and are afflicted for their religion's sake with grievous and exqusite tortures". ${ }^{12}$ In this context it should be remembered that Persons' account had the form of a letter to a friend-Gerard.

In any case, the history of the English mission was becoming more famous in Polish society every year, and mostly to the credit of Piotr Skarga. As the author of Żywoty s'więtych [Lives of the Saints] he had shown a lot of interest in the past and present of the far off kingdom. While including the lives of twenty English saints in his great hagiographic collection, Skarga supplemented them with short historical passages, but, as Stanisław Windakiewicz noted, "he studied the past of the English Church first of all in order to have a reason for speaking with some competence about the present". ${ }^{3}$

The most important expression of this interest in the contemporary English social and religious upheaval was Przydatek [...] o świętych męczennikach, którzy tych naszych wieków dla Chrystusa, prawdy i Kościoła Jego

which was testified to by his innocent, and angelic face, for he was a comely youth and was not yet twenty eight years of age" (Okrucieństwo kacyrskie, 174). Similarly in Concertatio: "[...] in stadium prodiit Alexander Briantus, iuvenis sane pulcherrimus (quippe qui vigesimum octavum aetatis annum nondum excesserat) vultu vere innocens et prope angelico [...] (quoted after the edition Concertatio Ecclesiae Catholicae in Anglia adversus calvinopapistas et purotanos sub Elizabetha regina quorundam hominum doctrina et sancitate illustrium renovata (Trier, 1589), fol. 72 v.). Later, the same motif would be used by Skarga, who followed Concertatio: "[...] soon Alexander Briant was brought to the square, a comely young man and of flowering youth, who was not yet twenty-eight, with an angelic face [...]." Żywoty świętych Starego i Nowego Zakonu [The Lives of Saints of the Old and New Testament] (Krakow, 1585), 1131.

${ }^{11}$ Thomas M. McCoog, "Construing Martyrdom in the English Catholic Community, 15821602", in Catholics and the 'Protestant Nation'. Religious Politics and Identity in Early Modern England, ed. Ethan H. Shagan (Manchester: Manchester University Press, 2005), 105.

${ }^{12}$ Calendar of State Papers, Foreign Series, of the Reign of Elizabeth, January-June 1583 and Addenda, ed. Alfred John Butler and Sophia Crawford Lomas (London: His Majesty's Stationery Office, 1913), no. 723.

${ }^{13}$ Stanisław WindaKIEwiCz, "Skarga i Anglicy [Skarga and Englishmen]," Sprawozdania z Czynności i Posiedzeń Polskiej Akademii Umiejętności 25 (1920), No. 4: 4. 
świętego cierpieli [A Supplement [...] About the Saint Martyrs Who In Our Centuries Suffered for Christ, the Truth and His Holy Church], whose first part (not counting Przedmowa o męczennikach heretyckich-A Foreword On Heretical Martyrs) is constituted by the story $O$ męczennikach $w$ Anglijej [On the Martyrs in England]. Skarga begins his narration with the history of Henry VIII and his apostasy, the martyrdom of John Fisher and Thomas Moore, the Carthusians (John Houghton, Robert Lawrence, Augustine Webster) and an unidentified Reginald, a theology doctor (maybe it is just Saint Richard Reynolds of the Bridgettine Order who accompanied the Carthusians in their martyrdom), John Haile and the following groups of English Carthusians, Augustinians and Cistercians. His account has almost the character of a chronicle, supplemented with information (very sparing, it has to be admitted) concerning the further vicissitudes of the King and his offspring. Skarga does not mention the oppression of Protestants during Queen Mary's reign at all, in accordance with the view presented in Przedmowa o męczennikach heretyckich that they were the ones who were "justly and legally punished by the orderly lay office given by God, for their spite, soulbanditry, falseness, treasons, sacrileges, disobediences, riots and mutinies". ${ }^{14}$ Indeed, Mary Tudor's reign was the time when "God's Church, remedied, had a little peace and coolness in England [...]". ${ }^{15}$

The hagiographer devotes most of his attention to the oppression of Catholics during Elizabeth I's reign. In the first edition of his work he calls her "a second Jezebel", "a daughter of an evil bed", "a popess". ${ }^{16}$ However, he does not discuss the first Elizabethan martyrs individually. Citing Nicholas Sanders, he gives the number of people belonging to particular classes, usually omitting their names, and adds sometimes the descriptions of their executions or miracles. Finally, he gives a number of five hundred Elizabethan martyrs - which is probably too high (especially in 1579), even if we consider the fact that many Catholics simply died in prison and their fates remained uncertain. ${ }^{17}$ Skarga only mentions Thomas and Christopher Nortons,

\footnotetext{
${ }^{14}$ Piotr SKARGA, Żywoty świętych Starego i Nowego Zakonu (Wilno, 1579), 1121.

${ }^{15}$ Ibid., 1125.

${ }^{16}$ Ibid. On this subject see: Janusz TAZBIR, "Elżbieta I Tudor w opinii staropolskiej [Elizabeth Tudor in the Old-Polish Opinion]," Odrodzenie i Reformacja w Polsce 34 (1989): 49-70.

${ }^{17}$ The issue of English martyrs was presented in the Holy See for the first time in 1874. The list included 360 people executed in the years 1535-1683, of which the Catholic Church officially, in a trial that had already lasted over one hundred years, recognized 342 as saints or blessed. However, many cases and trials remain undocumented, so the number is surely incomplete. The list of Catholic English martyrs to only a very small degree considers the lay faithful who most often died in prisons. See Goeffrey F. Nuttall, "The English Martyrs 1535-1680: A Statistical
} 
as well as John Felton and John Story, by name, although when his work was printed in the Vilnius press there were already many more martyrs in England. He himself emphasizes that Nicholas Sanders's work De visibili monarchia Ecclesiae libri octo was his main source at this stage of his work; it had been published in Leuven eight years before, that is, before the Elizabethan persecutions sharply increased (anti-Catholic decrees were published by the Queen's order in the same year, that is, in 1571). ${ }^{18}$ In Book Seven of Sanders's great work the names of Elizabethan victims (including exiles, prisoners, those deprived of their properties, offices etc.) are listed, and although the list itself was not quoted by the Polish writer, his estimation of the number of martyrs during Elizabeth's reign was probably based on Sanders, but without indicating what type of oppression or maltreatment they had suffered.

By a particular twist of fate, the history of the Jesuit mission in England of 1580 became, albeit indirectly, part of our writer's own personal history, which probably influenced the fact that in the 1585 edition of Żywoty swiętych the events connected with it were presented at great length. In this edition, in the description of Campion and his companions' trial we find the following passage:

Along with them holy and very well learned priests were condemned to the same kind of death: Radulphus Servinus, Lucas Chirbeus, Iacobus Bosgravius, Cothamus and Iansonus, Alexander Briantus. Iacobus Bosgravius and Cothamus were also ex Societate Iesu. Being an unworthy elder I sent this Bosgravius from Vilnius, where he taught mathematics and being an Englishman learned the Polish language well, to his martyrdom, by the Reverend General's order. I remember you, most beloved brother, when you asked me for the mantle that I had brought from Italy, for your journey, and when I put it on you, and Christ chose you for his witness and armed for such a martyrdom. ${ }^{19}$

Review", The Journal of Ecclesiastical History 22 (1971), No. 3: 191-197; William MonTER, "Heresy Executions in Reformation Europe, 1520-1565," in Tolerance and Intolerance in the European Reformation, ed. Ole Peter Grell and Bob Scribner (Cambridge: Cambridge University Press, 2002), 48-65. On the issue of martyrdom in early modern Europe see the book by Brad S. Gregory, Salvation at Stake. Christian Martyrdom in Early Modern Europe (Cambridge, Mass., London: Harvard University Press, 1999).

${ }^{18}$ Andrea Ceccherelli, Od Suriusa do Skargi. Studium porównawcze o „Żywotach świętych" [From Surius to Skarga. A Comparative Study on "The Lives of Saints"] (Izabelin: Swiat Literacki, 2003), 103. On Nicholas Sanders (vel Sander or Sanderus) see: John A. WAGNER, Sander, Nicholas, in Encyclopedia of Tudor England, ed. John A. Wagner and Susan Walters Schmid (Santa Barbara: ABC-CLIO, 2012), 987-988; Henryk ZINs, Polska w oczach Anglików XIV-XVI w. [Poland through Englishmen's Eyes in the $14^{\text {th }}-16^{\text {th }}$ Centuries] (Warszawa: Państwowy Instytut Wudawniczy, 1974), 131-132; Thomas McNevin VeEch, Dr. Nicholas Sanders and the English Reformation 1530-1581 (Louvain: Bureaux du Recueil, Bibliothèque de l'Université, 1935); John Hungerford Pollen, "Dr. Nicholas Sanders, $16^{\text {th }}$ Century Catholic Controversialist", English Historical Review 6 (1891): 36-47

${ }^{19}$ Piotr Skarga, Żywoty świętych Starego i Nowego Zakonu (Kraków, 1585), 1130. This 
Undoubtedly, it was exactly this "Bosgravius", that is James Bosgrave, who constituted the biographical, and hence essential, iunctim between the history of the English mission and the writer himself. In 1580, Skarga was rector of the Vilnius Academy where that young Englishman, only thirty years old at the time, the son of a noble family from Dorsetshire, was a professor of mathematics. Bosgrave had studied in Rome and was ordained a priest in Olomouc. ${ }^{20}$ Actually, this was not unusual; in Vilnius other newcomers from the British Isles also lectured, including the Scotsman Robert Abercrombie, the Englishman Adam Brook, and later Richard Singleton and Arthur Lawrence Faunt. ${ }^{21}$ Vilnius was not the first Polish place Bosgrave lived in, although the issue is not quite clear. He surely worked in the College in Pultusk in 1575, and it is possible that earlier he stayed in Poznań and in Kraków for some time. ${ }^{22}$ In any case, beginning in 1574 Bosgrave applied for permission to leave Poland; his letters to the General, Father Everard Mercurian, asking him to agree to his going to Rome, Vienna, Leuven or anywhere that the Superior would like to send him, have been preserved. The young Jesuit wanted to continue his theological studies, which was not possible in Poland; moreover, Polish winters undermined - as he said - his

wistful mention about the mantle given to the young Englishman disappears, which is significant, from the next editions. Skarga clearly learned that ultimately Bosgrave avoided death, and probably also knew about the rather unclear (see below) circumstances of his release from prison. In this new context, the Polish writer preferred not to emphasize the issue of his subordinate's martyrdom and therefore he replaced the address that he probably found too emotional with the following note: "Being an unworthy elder I sent this Bosgravius from Wilnius, where he taught mathematics and being an Englishman learned the Polish language well, to his martyrdom, by the Reverend General's order. The death of the others was put off, and with time Bosgravius, owing to a letter by King Stephan to the English Queen, in which he recommended the Catholics and this Bosgravius as his own to her, was saved from death." Piotr SKARGA, Żywoty świętych Starego i Nowego Zakonu (Kraków, 1589), 1134.

${ }^{20}$ Wacław Borowy, "Prześladowani katolicy angielscy i szkoccy w Polsce XVI wieku [The Persecuted English and Scottish Catholics in Poland in the $16^{\text {th }}$ Century]," Przeglad Powszechny 1938, No. 7-8, 115-116; ZINS, Polska w oczach Anglików, 139-140.

${ }^{21}$ Michał BALIŃSKI, Dawna Akademia Wileńska. Próba jej historyi od założenia w roku 1579 do ostatecznego przeksztatcenia w roku 1803 [The Former Wilnius Academy. An Attempt at Its History Fom Its Establishment in 1579 to the Final Restructuring in 1803] (Petersburg: J. Chryzko, 1862), 76-83.

${ }^{22}$ Thomas M. McCoog, “'Godly Confessor of Christ': The Mystery of James Bosgrave,” in: Jezuicka ars historica. Prace ofiarowane ks. prof. Ludwikowi Grzebieniowi SJ [The Jesuit Ars Historica. Works Dedicated to Rev. Prof. Ludwik Grzebień SJ], ed. Marek Inglot and Stanisław Obirek (Kraków: WAM, Ignatianum, 2001), 357. The English spy John Rogers (more about him below) in his denunciation written to Francis Walsingham mentioned these Polish places where Bosgrave had stayed before. For Rogers' denunciation see Calendar of State Papers, Foreign Series, no. 590 . 
health. ${ }^{23}$ Despite these efforts Bosgrave stayed in Vilnius (at the end of 1578 and the beginning of 1579 he only made a short journey to Stockholm) and at the end of July 1578 he started asking the General to agree to his move to England. These requests, justified by a rather vague desire to reinforce his family and friends' faith, as well as by his hope for the healing effect of the English air, did not receive a reply until the moment when news arrived in Vilnius about the imprisonment of Nicholas Bosgrave, the Jesuit's brother. In these new circumstances, Bosgrave repeated his request and Mercurian authorized Provincial Sunyer to make the decision. Bosgrave received his longed-for permission to go to England. In the letter to the General that he wrote before his journey he assured his superior that he would try to contact the Fathers of the Society who had been just sent from Rome. ${ }^{24}$

At the end of August 1580, in Elsinore in Denmark Bosgrave unfortunately met an English agent, John Rogers, who soon realized that his interlocutor was a Jesuit and, what is worse, having intercepted his letters he started to suspect that he was going to England on an important mission. As Pawel Skwarczyński stated, Rogers' letter of denunciation probably travelled to England on the same boat as Bosgrave. ${ }^{25}$ The monk was captured nearly immediately, at the beginning of September, in Orford, Suffolk. After which, there begins the bizarre and still mysterious story of his imprisonment and later trial that Skarga mentions in the passage quoted from Żywoty świętych.

Bosgrave, who left England as a fifteen-year-old boy, probably did not know much about the realities of political-religious life in his homeland. Confronted with the Privy Council, not only did not he try to conceal his identity but in reply to the question if - as the Queen's loyal subject-he was going to participate in services of the Church of England he replied that he could not see a reason why he should not do so. He did not know (he was not in England at that time $)^{26}$ that the aforementioned July synod in Southwark had authoritatively decided on the issue of Catholics' participation in Anglican services. But Bosgrave's naïve reply and its consequence, his presence at Protestant services, caused, on the one hand, him to be released and treated in a friendly manner by the authorities, and on the other that the faithful Catholics were outraged seeing that he walked in the streets of London without being troubled by anybody, while others were put in prison for

\footnotetext{
${ }^{23}$ McCoog, “ 'Godly Confessor of Christ': The Mystery of James Bosgrave”, 357-358.

${ }^{24}$ Ibid, 359-361.

${ }^{25}$ Paweł SKWARCZYŃSKI, "Elsinore 1580: John Rogers and James Bosgrave," Recusant History 16 (1982): 7.

${ }^{26}$ Ibid, 7, 15.
} 
merely refusing to take part in Anglican ceremonies. Only after some time did a friend or his brother make him realize the complexity of the situation, which immediately made Bosgrave react and make expiations. He sent a letter to the Privy Council in which he canceled his previous declaration and, moreover, he published something akin to an open letter to English Catholics known as The satisfaction of M. James Bosgrave, the godly confessor of Christ, concerning his going to the Church of the Protestants at his first coming into England, in which he declared that he would not enter Protestant churches with the intention of praying or of joining the "sect". 27 These letters resulted, obviously, in his immediate arrest and imprisonment, first in Marshalsea, and then in the Tower.

Robert Persons' account De persecutione Anglicana contains mentions of the torture that was inflicted upon Bosgrave, and gives the first description of the trial, in which the Vilnius professor, who became a part of the history of the Jesuit mission almost by mistake, stood side by side with Edmund Campion and his companions. And in Okrucieństwo kacyrskie one could read that "in the year 1581, on the $20^{\text {th }}$ of November, when Saint Edmund King of England is celebrated in England, these priests are taken to court: Edmundus Campianus, Jacobus Bosgravius - fathers of the Society of Jesus [...] However, they roughed up Campianus, Servinus, Briantus, Jansonius, Bosgravius and others, manhandling all their members and nearly tormented them to death on a rack". ${ }^{28}$ A rack (equleus, translated into Polish as 'konik' - 'a little horse') is an instrument of torture used to stretch the body and pull the limbs out of the sockets. At two points in his account Persons confirms that Bosgrave, after he had been transferred to the Tower, was tortured in this way.

Nevertheless, the young Jesuit, even though he was sentenced to death, was not executed together with Campion, Sherwin and Briant at Tyburn, on the outskirts of London. Immediately after the trial he was put in the Tower again. This mystery was solved only in modern times by Thomas M. McCoog who, analyzing the letters written by Bosgrave himself and by his superiors, found that it is most likely that there was a grain of truth in the Anglican pamphlets published several months after the trial, whose authors stated that while answering the so-called bloody questions, which were the basis for the accusation of high treason, Bosgrave and Henry Orton gave re-

\footnotetext{
${ }^{27}$ For extensive quotations from Bosgrave's memorandum see: SKWARCZYŃSKI, "Elsinore: 1580,”. 8; McCooG, “'Godly Confessor of Christ': The Mystery of James Bosgrave,” 364-365.

${ }^{28}$ Okrucieństwo kacyrskie, 160-161.
} 
plies that were different from the ones given by Campion and his companions. McCoog thinks that the Vilnius Jesuit, although he consistently rejected the Queen's authority in spiritual matters, recognized her lay authority and, what is more important, denied that the Pope could deprive Elizabeth of this authority (on the strength of the bulla Regnans in excelsis of 1570 excommunicating the Queen). ${ }^{29}$ This was, obviously, inconsistent with the stand of the Society of Jesus, but probably saved Bosgrave's life. On the other hand, it is hard not to take into consideration the fact that he was not the only clergyman sent to prison after the trial. According to an account by one of the accused, Edward Rishton, there were several of them, and ultimately, after a few years, several dozen were banished, including Rishton himself. ${ }^{30}$

Bosgrave remained in the Tower until 1585, when his death sentence was finally commuted to banishment. After staying in France for more than a dozen years he returned to Poland, first sent to the college in Braniewo, then to Poznań, and finally to Kalisz, where he died in 1623 with a reputation for saintliness. His superiors were conscious of the weakness he showed when he faced his ordeal and considered expelling him from the order, butthanks to Persons' intercession, among other things - they decided that he should be forgiven. ${ }^{31}$ Bosgrave himself, ill and exhausted, spent the last years of his life primarily devoting his time to looking after the poor.

Skarga was not - as may be supposed - indifferent to Bosgrave's fate, so peculiarly inscribed in the history of the Jesuit mission, although it seems that for a long time he was not sure what in fact had happened to his Vilnius subordinate. More than likely he tried (as he later did in the case of Henry Garnet) to cause a diplomatic intervention (which ultimately did take place). Stephen Báthory's first letter to Queen Elizabeth concerning the imprisoned Catholics that is known of was written on the $29^{\text {th }}$ of January $1583 .{ }^{32}$ But a letter written by the King's Preacher Marcin Laterna to Piotr Skarga, dated the $1^{\text {st }}$ of August 1581 (so before the trial!), contains a mention of the King intervening in the case of the innocent Jesuits imprisoned in England; and

\footnotetext{
${ }^{29}$ McCoOG, “'Godly Confessor of Christ': The Mystery of James Bosgrave,” 370-374.

${ }^{30}$ Rishton, inspired by Persons, wrote Book Four of the work that Nicholas Sanders did not finish, De origine ac progressu schismatic Anglicani (the first edition, 1585). Chapter Eleven of the book is just about the banishment of the clergymen, among them Bosgrave and Rishton himself. The work, reissued many times, was also published an Poland in 1690 , and in the $18^{\text {th }}$ century its large portions were translated into Polish by Jan Poszakowski.

${ }^{31}$ MCCoOG, "'Godly Confessor of Christ': The Mystery of James Bosgrave," 374. no. 707

${ }^{2}$ For the English summary of the letter see: Calendar of State Papers, Foreign Series,
} 
one of them was Bosgrave, although no names are mentioned in Laterna's letter. $^{33}$

Preparing the second edition of Żywoty swiętych mentioned above, in which Przydatek [...] o świętych męczennikach, którzy tych naszych wieków dla Chrystusa, prawdy i Kościoła Jego świętego cierpieli was considerably extended, mainly owing to a description of the history of Campion's mission, Skarga already had at his disposal many other texts on this subject, especially Concertatio Ecclesiae catholicae in Anglia (1583), which he used to a large degree as his basis. Both Przedmowa o męczennikach heretyckich and the narration on martyrs of the time of Henry VIII remained essentially unchanged in this edition (and in all the next ones), but it was exactly the history of the Jesuit mission that became the core of the disquisition on the persecutions of Catholics in England:

In modern times about Anno Domini 1580 and later also, there, in England many other people are murdered for professing the Catholic faith who are priests, God's prophets of great virtue, innocence and learning, who due to love of God and of their neighbours gave aid and support in the perseverance in Christ's truth to exasperated Catholics in their homeland. Among others, Edmundus Campianus Societas Iesu on the $1^{\text {st }}$ of December Anno Domini 1581, is martyred. He, having been born in London and taught among heretics in Oxonium [Oxford], a man of great wit and elocution, was made a deacon in the Anglican Church; in which he saw his heretical error owing to God's light and in Douai in Flanders he performed penance for his sin; and abandoning all the world he headed for the Societas Iesu order and was received in Rome, and then sent to Prague, Czechia; he perfected his great love of God and virtues, as well as he achieved excellence in learning, in writings and in understanding. He was also a man of unusual and great elocution with which he both strengthened the emperor with all his court in his Latin sermons, and made numerous heretics recognize the truth. From Prague he is summoned to Rome by his General Everard Mercurian and from there soon he is sent to save his homeland and Catholics in England, as if he was sent to his death. [...] Having entered England secretly he made his presence known with an open letter requesting the Queen to give him safe conduct and let him have disputations and talks with the selected most eminent ministers of all England. And when ministers in open letters recognized this as stupidity and pride, and the Queen denied him safe conduct, he replied with a short and unusually learned writ giving ten causes that made him want to enter the talks. Which, as it is translated into Polish, anybody can read. Meanwhile, for thirteen months secretly travelling all over England, com-

33 "Si tamen contra discretionem non pecco, rogo ut $\mathrm{R}$ [everendissim]a V[est]ra meo quoque nomine illum per $\mathrm{R}$ [everend]os Patres, qui cum eius $\mathrm{R}$ [everendissi]ma $\mathrm{D}$ [ominatio]ne prandere solent, salutari iubeat. Egit et nunc M[aiesta]ti Regiae gratias pro literis ad Reginam Angliae datis in eorum causa et negotio, qui innocenter in vincula ab ea ex nostra Societate coniecti sunt." (quoted after the edition: Listy Ks. Piotra Skargi z lat 1566-1610 [Rev. Piotr Skarga's Letters of the Years 1566-1610], ed. Jan Sygański (Kraków: Wydawnictwa Towarzystwa Jezusowego, 1912), 155. In Skarga's correspondence, including his own letters, the efforts made in 1605 in the case of Henry Garnet are best documented. See e.g. p. 267-269. 
forting old Catholics with greatly sweet sermons and gaining a great number of new ones, he is captured through some Eliot's treason $[\ldots] .{ }^{34}$

A characteristic mention of the Polish translation of Campion's Rationes decem emphasizes Skarga's special interest in his person. The writer is referring here first of all to the translation he himself did and which had been published a year before the second edition of Żywoty siwietych appeared in print, that is, to the work Dziesięc wywodów, dla których Edmund Kampianus z Londynu, Societas Iesu, wszystkie heretyki w Anglijej co najuczeńsze na dysputacyja okoto wiary wyzwat, pisane od niego do Akademijej Oksonieńskiej i Kantabryjskiej. A dla lepszego zrozumienia rzeczy tej położone sq na przodku dwa listy jego: jeden do rad i senatu królestwa angielskiego, drugi do generała Societatis Iesu. A na końcu męczeństwa jego krótka historyja dotożona jest [Ten Reasons why Edmund Campion of London, Societas Iesu, challenged all most learned jeretics in England, written by him to the Oxford and Cambridge academies. And for a better understanding of the matter at the beginning his two letters are put: one to the Councils and Senate of the English Kingdom, and the other to the Superior General of Societas Iesu. And at the end a short history is added of his martyrdom] (Vilnius 1584, in the Radziwiłł's press). Even this "table of contents" contained in the title indicates that Skarga used the first edition of Concertatio Ecclesiae catholicae in Anglia as the source of information; Concertatio provided the complete text of Rationes decem, Campion's letter to the Privy Council (the so-called Campion's Challenge) and one to Father Everard Mercurian, as well as, obviously, vita et martyrium. Skarga by no means considers $R a$ tionem decem a literary relic, but presents it - and this will not change in all of Europe for at least until the middle of the $17^{\text {th }}$ century - as an important apologetic text. ${ }^{35}$ Interest in both the text and in the personage of Edmund Campion had been very great at that time in Poland-Lithuania, for in the same year, that is 1584 , and perhaps in the same town, that is Vilnius, another, utterly independent Polish translation was printed. Its author was Kasper Wilkowski, a Lublin physician, who just a year earlier had left - under the influence of the Jesuits - an Antitrinitarian congregation and converted to Catholicism. Wilkowski published his work while being fully aware that he had just been forestalled by Skarga. In a dedicatory letter to Queen Anna Jagiellon who was characterized here as a stark contrast to Elizabeth Tudor, he wrote about Campion's works:

\footnotetext{
${ }^{34}$ SKARGA, Żywoty świętych Starego i Nowego Zakonu (1585), 1129-1130.

${ }^{35}$ Jean-Louis QuAntin, The Church of England and Christian Antiquity. The Construction of a Confessional Identity in the $17^{\text {th }}$ Century (Oxford: Oxford University Press, 2009), 57.
} 
In that work he wrote these little books [...]. And also I, having been given them by His Lordship and Father Hieronim Rozrażewski, the Kuyavian Bishop, and much in the Catholic faith by them and by the exemplary communion of His Lordship as a righteous pastor reinforced, I wanted very much all the people to benefit from this good and I gave the books to many people to read. However, knowing that I could not satisfy my desire and meet everybody's needs, I undertook it with God's help and His Lordship's advice, having translated them into our Polish language, for those who do not know Latin, to publish them, devoting my time that was left from the service to His Lordship's health and other occupations of my vocation. And I would have published them long ago, but having learned that Rev. Piotr Skarga Societatis Iesu, a man of great gifts and a diligent and lucky worker in the Lord's vineyard, started the same work on His Majesty the King's order, I threw them away, until Rev. Skarga himself, with his writings, among other persuasions mentioning my printing indiligence, forced me to publish them. ${ }^{36}$

The dedication is dated from Vilnius, and since Wilkowski printed his other works exclusively in Vilnius, it may be assumed that the book was also published there. ${ }^{37}$ Perhaps Skarga's translation of Rationes decem was so quickly sold out that he simply encouraged Wilkowski to publish his own work? This would indicate a considerably greater interest amongst Polish readers in the events connected with the Jesuit mission in England than could have been expected. This thesis is confirmed by a further reading of the book by the Lublin convert: besides the very translation of Rationes decem we also find there Krótka sprawa o autorze tych ksiażek i odpisie na nie, $i$ o odpowiedzi na „Przyczyny nawrócenia” Gaspra Wilkowskiego [A short description of the author of these books, and about how they and Gaspar Wilkowski's "The Causes of Conversion" were replied]. This part of the work contains, among others, a brief summary of Campion's letter to the members of the Privy Council (with extensive quotations), a short description of his martyrdom, and, what is important, a discussion of the history of the polemics started by Campion's writings. Wilkowski mentions the first

\footnotetext{
${ }^{36}$ Kasper Wilkowski, Dziesięć mocnych dowodów, iż adwersarze Kościoła powszechnego w porzqdnej o wierze dysputacyjej upaść muszq, Edmunda Kampiana Societatis Iesu. Z tacińskiego na polski język z pilnościq przettumaczone i potrzebnie wydane, z krótka sprawa jego męczenniczego dokonania i odpisu Witakierowego. A przy tym na Antidotum kalwińskie odpowiedź i z nowokrzczeńcami rozprawa z strony „Przyczyn nawrócenia” Gaspra Wilkowskiego [Ten strong arguments that the adversaries of the Catholic Church in an orderly dispute about the faith have to fall, by Edmund Campion Societatis Iesu. From Latin into Polish diligently translated and published with a short summary of his martyrdom and of the Whitaker's reply. And also, a reply to the Calvinist Antidote and a dispute with the Antitrinitarians in regards to Gaspar Wilkowski's "Reasons for Conversion"] (s. 1., 1584).

${ }^{37}$ Wilkowski worked as Hieronim Rozrażewski's physician only for several weeks, in May and June 1584. Korespondencja Hieronima Rozrażewskiego, vol. 2, ed. Paweł Czaplewski (Toruń: Towarzystwo Naukowe w Toruniu, 1939-1947), 170, 182, 191-192.
} 
adversaries of the English Jesuit, William Charke and Meredith Hanmer who, as early as 1580, replied to his letter To the Right Honourable Lords of Her Majesties Privy Council, and he devotes most of his attention to the leading Cambridge theologian of that time, William Whitaker, the author of Ad rationes decem Edmundi Campiani Iesuitae, quibus fretus certamen Anglicanae Ecclesiae ministris obtulit in causa fidei responsio (London, 1581), who was also famous as an adversary of Bellarmino and Stapleton ${ }^{38}$ :

To these books a certain Calvinist Whitakerus replied to the murdered Campion in his way, that is denying the charges and defending them, hereby mixing everything and making it difficult. Also in Poland there are some people triumphant with his reply, but let them know that when Whitaker was boasting about the spoils he had ripped off that dead Hector, Ioannes Dureus Scotus bravely reclaimed them, and broadened Campion's work and thoroughly consolidated it. And be it God's will, it may also appear in the Polish language so the common people could save themselves the same way they had been harmed, which is by reading in Polish tongue $[\ldots] .{ }^{39}$

Wilkowski says directly here that Whitaker's works are known in Poland and they are used in religious polemics ("in Poland there are some people triumphant with his reply"). "Duraeus Scotus" is the Scottish Jesuit, John Dury, the author of Confutatio responsionis Gulielmi Whitakeri in Academia Cantabrigensi Professoris regii, ad Rationes decem, quibus fretus Edmundus Campianus Anglus certamen Anglicanae Ecclesiae ministris obtulit in causa fidei (Paris, 1582). Indicating the Polish dissident polemists who used Whitaker's works and arguments in 1580 s would require a separate analyses, but it seems that first of all the outstanding Calvinist writer Andrzej Wolan's works should be studied from this point of view - at that time he was a fervent adherent and apologist of Elizabeth I. ${ }^{40}$ Whitaker, as Campion's polemist (triumphant, of course), is also mentioned in Apologia Andreae Volani of $1587,{ }^{41}$ and it may be expected that in Wolan's earlier works his interest in the Jesuit-Anglican theological dispute could have been manifested. The truly international character of these controversies is indeed astonishing; as Janusz Tazbir wrote: "In the epoch of religious wars in fact one "common market' of religious polemics was formed and fairly frequently replies were given in works published in Italy or France to a book printed in Raków, Vil-

\footnotetext{
${ }^{38}$ Henk VAN DEN BeLt, The Authority of Scripture in Reformed Theology: Truth and Trust (Leiden: Brill, 2008), 125-132.

${ }^{39}$ WiLKOWSKI, Dziesięć mocnych dowodów, 67.

${ }^{40}$ TAZBIR, “Elżbieta I Tudor,”. 62.

${ }^{41}$ Andrzej Wolan, Apologia [...] ad calumnias et convitia pestiferae hominum sectae, qui se falso iesuitas vocant (Wilno: Per Danielem Lancicium, 1587), fol. C1 v.
} 
nius or Brest-Litovsk; and on the other hand a polemic started on the Tiber, the Rhine or the Seine found its continuation just in Poland". ${ }^{42}$ The range of these interactions, especially with respect to Polish-English relations, is not yet examined and would seem to be an important field of research.

In Wilkowski's interpretation, the English mission of 1580 is first of all a heroic clash of theological arguments, in which, on the one hand, martyrs testify to the truth with their own blood, and on the other entrust their followers with the task of continuing the struggle, an example being of the hitherto mentioned John Dury who continued Campion's disquisition when the latter could not refute his adversaries' arguments any more, or Wilkowski who, in an extraordinary way, includes his own dispute with Polish Calvinist and Antitirinitarian theologians into the current of the English debate:

[...] and hence Polish Catholic books are of benefit indeed and it bothers the adversaries a lot, because as soon the books are printed, they revile and suppress them with their replies. As my books of this year (as I will put off Whitaker for some other time), simply showing the causes of my conversion, could not be free of that; all sorts of arrays attacked them with mouths and with pens. ${ }^{43}$

Ultimately it seems, Wilkowski never translated the works by Whitaker and Dury, but he annoted his translation of Campion's work with references to the doctrine of his former co-religionists and added his own short reply to their accusations. His adversaries were: Grzegorz of Żarnowiec, a Calvinist who only a year earlier had attacked him in Antidotum albo lekarswo na odtręt od ewangelików pana Kaspra Wilkowskiego, medyka lubelskiego [An Antidote or Medicine for the Lublin Physician Master Kasper Wilkowski's departure from the Evangelicals] (place of publication not given, 1583), and Jan Niemojewski, a senior minister of the Antitrinitarian congregation in Lublin. Wilkowski clearly considered his undertaking as a continuation of the Catholic-Calvinist theological struggles crossing the borders of countries and languages. Edmund Campion, whose martydom was, as mentioned, "shortly" described by Wilkowski in Dziesięć mocnych dowodów, appears as the patron of Catholic apologetics of that time. On one hand, he is an outstanding polemist, and on the other - he is the one who, in the Tower, although tortured on the rack and deprived of books and libraries, entered into debate with Anglican ministers and, owing to the inspiration of his faith in the Holy Spirit, he emerged victorious from them:

\footnotetext{
${ }^{42}$ Janusz TAZBIR, Piotr Skarga. Szermierz kontrreformacji [Piotr Skarga. A Champion of the Counter-Reformation] (Warszawa: Wiedza Powszechna, 1978), 51.

${ }^{43}$ WILKOwSKI, Dziesięć mocnych dowodów, 67
} 
They led him to an open dispute with the hope that - haggard and worn out - his memory and his reason would be failing, but the One, who was tormented and drawn in his body, could not be weakened and so could not His word be tied; indeed, He gave him such wisdom and mouth against which they could not defend themselves, even though the dispute was long and hard for four days, with this strict condition that he was not allowed to ask about anything or present his view according to his need. ${ }^{44}$

The apology following the sparing description of Campion's martyrdom, directed at the Protestant polemists attacking Wilkowski - full of pain, testifying to the exceptional aggression with which those, who had until recently been his co-religionists, reacted to the Lublin physician's conversion - is inscribed in this paradigm of the "martyrdom of polemics", the heroism of debate, in which suffering, physical or spiritual, becomes an additional sacrifice and at the same time seals doctrinal truth.

In Skarga's Żywoty świętych, which without a doubt gave the most extensive and complete account of the events of the 1580 English Jesuit mission, this apologetic-polemical aspect was also fully emphasized:

\begin{abstract}
Worn out by those torments and hunger, when he was not able to walk, or move neither of his arms, he was led to an open disputation with the ministers who first had a dispute with him by means of torment, of ropes, of drawing and joint dislocation, hunger, stench and of dark ties. Oh, the lion's and devil's cruelty, unheard of with Neros and Diocletians! After all they first talked and disputed with healthy ones, and allowed St Catherine to be healthy when debating with philosophers. However, God did not stop working miracles in his witness; all other body members did not do their service, but the tongue and breast were strengthened, and reason gained God's strength to challenge the adversaries of the truth. Debating with them for four days, three hours in the morning and three after dinner, he achieved a great triumph, despite being so tied by them in the tongue and in freedom. Because at the beginning they forbade him to ask about anything or to support his Catholic truth, but only wanted him to answer their arguments. Oh, unbearable injustice! In this way they had to recognize themselves as losers. Many clandestine and overt Catholics were consolidated by this dispute, and many heretics converted to the truth. The devil only gained disgrace and loss, and Christ and His truth gained reverence and spiritual benefit. ${ }^{45}$
\end{abstract}

More clearly than Wilkowski, Skarga based his text on Concertatio Ecclesiae Catholicae in Anglia, although generally he uses this source in a free way, summarizing rather than translating $i t^{46}$ and, moreover, he seems to

44 Ibid, p. 66.

${ }^{45}$ SKARGA, Żywoty świętych Starego i Nowego Zakonu (1585), 1130.

${ }^{46}$ Elements of the translation may be illustrated in only few fragments of the account, the most obvious being those devoted to Alexander Briant, cf. e.g.: "After these two soon Alexander Briant was brought to the yard; he was a comely young man and one of flowering youth, who was not yet twenty-eight years of age, with an angelic face and greatly learned. He, when they put him on the cart, and tied to the scaffold by his neck, confessed his faith and swore on his life that he 
take care to maintain the proportions between the description of the life of Father Campion himself and the account concerning his saint companions (utterly passed over by Wilkowski). ${ }^{47}$ Although Skarga says much about Sherwin and Briant, in his opinion it is undoubtedly just Campion, the Jesuit and martyr of the theological dispute, who shines divine light upon the events of the 1580 mission and the tragic execution of the $1^{\text {st }}$ of December 1581. Although Concertatio Ecclesiae Catholicae in Anglia allowed Skarga to organize more carefully than earlier the data concerning the English martyrs, he used the source only to list them in rather superficial and chaotic manner in a dozen or so lines, in spite of the fact that these stories of martyrdom were also extraordinarily dramatic. He did not develop this part of his Przydatek in later editions either. The 1580 mission seemed to be especially significant exactly in the perspective of the heroic intellectual-spiritual confrontation, sealed with the martyrs' blood. It is worth pointing to the fact that the very descriptions of martyrdom in Skarga's writings are rather sparing (especially if one considers the actual horror of the victims' cruel death) and by no means meant to excite the readers' imagination by describing the atrocities. The fact that Skarga did his translation so quickly, as well as his encouragement offered to Wilkowski to publish his own translation, show that he was deeply interested in propagating Campion's theological-ethical heritage, since in the English Jesuit he sees a master of apologetics and the controversial theology of his times, fearless in the struggle against heretics.

had never been to Rome, or to Reims, and professed himself a rightful Catholic, and all this, and declared that Pius V excommunicated the Queen, which all Catholics understand, and when he was reciting the psalm Miserere mei Deus, he was pushed. Cut off, he suffered by the executioner's rashness twice as much as others, for until his heart was taken out he was alive during the quartering. And what is more, when his head was cut off and all the bowels were pulled out, and the body put on the block, he raised his body from the earth. At which everybody had to be amazed as at a great miracle." Ibid., 1131; "Post duos hos gloriosissimi Christi martyres, in stadium prodiit Alexander Briantus, iuvenis sane pulcherrimus (quippe qui vigesimum octavum aetatis annum nondum excesserat) vultu vere innocens et prope angelico, in sacris litteris hauc mediocriter eruditus, et multarum virtutum splendore illustratus [...]. Cui Briantus: nec reus sum, nec eius modi morte dignus, nunquam Romae vixi, nec Remis eo tempore fui, quo Doctor Sanderus se in Hyberniam recepit. [...] Cum veru plus caeteris, ut suam de Pii V bulla sententiam disceret, urgeretur; se de illa quod omnes catholici credunt, credendumque Ecclesia proponit, sentire dixit, deinde se verum catholicum mori confessus, psalmumqe Miserere mei Deus exorsus, subducto curru suspensus est, maiore poena, ab carnificis negligentia, quam alii duo. Hic vero, quod mirum videri debet, post capitis amputationem, membrorum sectionem, cordis, intestinorum et viscerum exustionem, impositus trunco, cum ingenti omnium stupore, corpus e terra sublevavit." Concertatio Ecclesiae Catholicae in Anglia, 72v.

${ }^{47}$ On Skarga's translation-paraphrasing strategies in Żywoty świętych see the book by A. Ceccherelli, 120-134. 
It was on this plane that both Wilkowski and Skarga wanted to follow the martyr.

In Poland, Campion's writings were also published in Latin, by the Piotrkowczyk's press in Kraków, in which Skarga printed so many of his works. ${ }^{48}$ The year 1605 when these editions were published is the time of the Gunpowder Plot and the beginning of another, very violent wave of persecutions, one of whose victims was to be Henry Garnet. Reminding people of Campion's figure and his thoughts by way of those Latin editions was probably connected with the intention of citing his ethos as a heroic witness of the truth. The Jesuit mission in England was ongoing and had had more martyrs by that time, but in the Polish reception none of them was given as much fame. Even in 1748 Jan Poszakowski, a Jesuit, called Rationem decem "a book nearly golden", and speaking about Campion's life he never failed to mention the "sweet and salutary discourses" with which the martyr was to support equally magnates and the poor, both on the European continent and in England. ${ }^{49}$ The vision of the 1580 mission was so consolidated in Poszakowski's account (rooted in a translation of Sanders and Rishton's De origine ac progressu schismatic Anglicani, but extended with the help of other sources, among them fragments of the work by the Jesuit Mathias Tanner Societas Iesu Apostolorum imitatrix), albeit enriched by descriptions of miracles and not at all restrained in the descriptions of torture and executions, that in the Polish tradition it remained an image of the struggle of arguments and conquest made by the Word as carried by the witnesses faithful to Him till the end.

\section{BIBLIOGRAPHY}

BalińSKI, Michał. Dawna Akademia Wileńska. Próba jej historyi od założenia w roku 1579 do ostatecznego przeksztatcenia w roku 1803. Petersburg: J. Chryzko, 1862.

BASSET, Bernard. The English Jesuits from Campion to Martindale. Gloucester: Gracewing Publishing, 2004.

${ }^{48}$ Edmundi Campiani Societatis Iesu, qui non ita pridem pro Catholica religione in Anglia mortem oppetiit, oblati certaminis in causa fidei rationes decem redditae Academicis Angliae (Kraków, 1605); Vita et epistolae Edmundi Campiani Societatis Iesu (Kraków, 1605).

${ }^{49}$ Jan PoszAKOwSKI, Historyja o poczqtku odszczepieństwa Kościoła anglikańskiego $i$ wejściu do niego herezyi kalwińskiej i innych sekt. Z Mikołaja Sandera, Edwarda Rychtona i inszych po nich nastęujacych pisarzów dziejów angielskich zebrana i opisana [The History of the Beginning of the Dissidence of the Anglican Church and the Calvinist and Other Sects Joining It. Collected from Nicholas Sanders, Edward Rishton and other writers of the English history following them] (Warszawa: Collegium Societatis Jesu, 1748), 252, 265. 
Borowy, Wacław: "Prześladowani katolicy angielscy i szkoccy w Polsce XVI w." Przeglad Powszechny 1938, no. 7-8: 110-124.

Calendar of State Papers, Foreign Series, of the Reign of Elizabeth, January-June 1583 and Addenda, edited by Alfred John Butler and Sophia Crawford Lomas. London: His Majesty's Stationery Office, 1913.

CeCcherelli, Andrea. Od Suriusa do Skargi. Studium porównawcze o „Żywotach świętych” [From Surius to Skarga. A Comparative Study on "The Lives of Saints"]. Izabelin: Świat Literacki, 2003.

Czerniatowicz, Janina, and Czesław Mazur. Recepcja antyku chrześcijańskiego w Polsce. Materiały bibliograficzne, vol. I: XVI-XVIII wiek, Part 1: Autorzy i teksty. Lublin: Towarzystwo Naukowe KUL, 1978.

Gregory, Brad S. Salvation at Stake. Christian Martyrdom in Early Modern Europe. Cambridge, Mass.. and London: Harvard University Press, 1999.

Encyclopedia of Tudor England, ed. John A. Wagner and Susan Walters Schmid. Santa Barbara: ABC-CLIO, 2012.

Gibbons, John, and John Bridgewater. Concertatio Ecclesiae Catholicae in Anglia adversus Calvinopapistas et Puritanos sub Elizabetha regina quorundam hominum doctrina et sanctitate illustrium renovata [...], Augustae Trevirorum: Bock, 1589.

Hanusiewicz-LavalleE, Mirosława. "Okrucieństwo kacyrskie przeciwko katolikom w Anglijej, czyli polski głos w sporze o męczeństwo.” Odrodzenie i Reformacja w Polsce 56 (2012): $37-60$.

Holleran, James V. A Jesuit Challenge. Edmund Campion's Debates at the Tower of London in 1581, New York: Fordham University Press, 1999.

Kazanie, które miat X. Jan Conarius [...] w kościele tumskim poznańskim przy pogrzebie [...] Stanisława Sobockiego, edited by Piotr Lilio. Poznań: J. Wolrab, 1590.

Korespondencja Hieronima Rozrażewskiego, vol. 1-2, edited by Paweł Czaplewski. Toruń: Towarzystwo Naukowe w Toruniu, 1939-1947.

Korolko, Mirosław. "Poglądy polityczne i społeczne Hieronima Powodowskiego.” Odrodzenie i Reformacja w Polsce 12 (1967): 87-97.

Listy Ks. Piotra Skargi z lat 1566-1610, edited by Jan Sygański SJ. Kraków: Wydawnictwa Towarzystwa Jezusowego, 1912.

McCoog, Thomas M.: "Construing Martyrdom in the English Catholic Community, 1582-1602." In Catholics and the 'Protestant Nation'. Religious Politics and Identity in Early Modern England. ed. Ethan H. Shagan. Manchester: Manchester University Press, 2005.

McCoog, Thomas M.: “'Godly Confessor of Christ': The Mystery of James Bosgrave.” In Jezuicka ars historica. Prace ofiarowane ks. prof. Ludwikowi Grzebieniowi SJ, edited by Marek Inglot and Stanisłąw Obirek, 355-375. Kraków: WAM, Ignatianum, 2001.

McCoog, Thomas M. The Society of Jesus in Ireland, Scotland and England 1541-1588: "Our Way of Proceeding." Leiden: Brill, 1996.

Milward, Peter J. Religious Controversies of the Elizabethan Age: A Survey of Printed Sources, Lincoln: Scolar Press, 1977.

MONTER, William. "Heresy Executions in Reformation Europe, 1520-1565." In Tolerance and Intolerance in the European Reformation, edited by Ole Peter Grell and Bob Scribner, 48-65. Cambridge: Cambridge University Press, 2002.

NutTALL, Goeffrey F. “The English Martyrs 1535-1680: A Statistical Review." The Journal of Ecclesiastical History 22 (1971), No. 3: 191-197.

Okrucieństwo kacyrskie przeciw katolikom w Anglijej, krótko a prawdziwie przez jednego tegoż narodu opisane, a na polski język przełożone. Poznań: [J. Wolbram], 1582. 
[Persons, Robert]. De persecutione Anglicana epistola, Bononiae: Apud Io. Baptistam Algazarium 1581 [Rouen 1581].

Pollen, John Hungerford. "Dr Nicholas Sander." The English Historical Review 6 (1891), no. 21: 35-47.

PIECHNIK, Ludwik: "Działalność jezuitów na polu szkolnictwa w Poznaniu w XVI wieku.” Nasza Przeszłość 30 (1969): 188-189, 196.

QuAntin, Jean-Louis. The Church of England and Christian Antiquity. The Construction of a Confessional Identity in the 17th Century. Oxford: Oxford University Press, 2009.

SANDERS, Nicholas, and Edward RISHTON. De origine ac progressu schismatis Anglicani libri tres [...] aucti per Edouardum Rishtonum [...]. Ingolstadt: Ex officina Typographica Wolfgangi Ederi, 1587.

SKARGa. Piotr. Żywoty świętych Starego i Nowego Zakonu na każdy dzień przez caly rok, wybrane z poważnych pisarzów i doktorów kościelnych [...]. Do których przydane sq niektóre duchowne obroki i nauki przeciwko kacerstwo dzisiejszym [...], k temu kazania krótkie [...], Wilno, 1579.

SKARGA, Piotr: Żywoty świętych Starego i Nowego Zakonu na każdy dzień przez caly rok, wybrane z poważnych pisarzów i doktorów kościelnych [...]. Do których przydane sq niektóre duchowne obroki i nauki przeciwko kacerstwo dzisiejszym [...], k temu kazania krótkie [...]. Teraz znowuż [...] przegladane i rozszerzone [...], Kraków 1585.

SKARGA, Piotr: Żywoty świętych Starego i Nowego Zakonu na każdy dzień przez cały rok, wybrane z poważnych pisarzów i doktorów kościelnych [...]. Do których przydane sq niektóre duchowne obroki i nauki przeciwko kacerstwo dzisiejszym [...], k temu kazania krótkie [...]. Teraz znowu [...] czwarty raz w druk podane [...], Kraków 1598.

SKorUpSKA, Zofia. „Konarski Jan.” In Polski Stownik Biograficzny, vol. 13, edited by Emanuel Rostworowski, , 463-464. Kraków: Zakład Narodowy im. Ossolińskich — Wydawnictwo Polskiej Akademii Nauk 1967-1968.

SkWARCZYŃSKI, Paweł. "Elsinore 1580: John Rogers and James Bosgrave." Recusant History 16 (1982): 1-16.

TAZBIR, Janusz. "Elżbieta I Tudor w opinii staropolskiej [Elizabeth Tudor in the Old-Polish Opinion]." Odrodzenie i Reformacja w Polsce 34 (1989): 49-70.

TAZBIR, Janusz. Piotr Skarga. Szermierz kontrreformacji [Piotr Skarga. A Champion of the Counter-Reformation]. Warszawa: Wiedza Powszechna, 1978.

The Contemporary Printed Literature of the English Counter-Reformation Between 1558-1640, edited A. F. Allison, D. M. Rogers, Aldershot: Routledge, 1989-1994.

The Reckoned Expense: Edmund Campion and the Early English Jesuits: Essays in Celebration of the First Centenary of Campion Hall, edited by Thomas M. McCoog, Oxford: Boydell \& Brewer, 1996.

VAn DEN Belt, Henk: The Authority of Scripture in Reformed Theology: Truth and Trust. Leiden: Brill, 2008

Veech, Thomas McNevin. Dr. Nicholas Sanders and the English Reformation 1530-1581. Louvain: Bureaux du Recueil, Bibliothèque de l'Université, 1935.

Wilkowski, Kasper: Dziesięć mocnych dowodów, iż adwersarze Kościoła powszechnego w porzqdnej o wierze dysputacyjej upaść musza, Edmunda Kampiana Societatis Iesu. Z łacińskiego na polski język z pilnościq przetlumaczone i potrzebnie wydane, z krótka sprawa jego męczenniczego dokonania i odpisu Witakierowego. A przy tym na Antidotum kalwińskie odpowiedź i z nowokrzczéncami rozprawa z strony „Przyczyn nawrócenia” Gaspra Wilkowskiego. ([s.1], 1584).

WindAKIEWICZ, Stanisław. "Skarga i Anglicy [Skarga and Englishmen]." Sprawozdania z Czynności i Posiedzeń Polskiej Akademii Umiejętności 25 (1920), No. 4: 1-8. 
Wolan, Andrzej. Apologia [...] ad calumnias et convitia pestiferae hominum sectae, qui se falso Iesuitas vocant, Wilno: Per Danielem Lancicium, 1587.

ZINS, Henryk. Polska w oczach Anglików XIV-XVI w. [Poland in Englishmen's Eyes in the $14^{\text {th }}-16^{\text {th }}$ Centuries]. Warszawa: Państwowy Instytut Wydawniczy, 1974.

\section{ECHOES OF THE 1580 JESUIT MISSION TO ENGLAND IN EARLY MODERN POLAND}

\section{S u m m a ry}

The article presents Polish reactions to the famous Jesuit mission in England of 1580, and thus also the beginnings of the formation of the worship of St Edmund Campion in Poland. They are connected with the publication in Kraków (1583) of a translation of Robert Persons' account entitled De persecutione Anglicana, but also with the position that the history of Campion's mission took in the work of Piotr Skarga SJ. The Polish writer, showing a lively interest in what was going on with English Catholics and inspiring political interventions in support of Jesuits imprisoned in England (including his subordinate, the Vilnius professor James Bosgrave), in subsequent editions of his very popular hagiographic collection Żywoty świętych [The Lives of Saints] presented Przydatek [...] o świętych męczennikach [A Supplement [...] on Saint Martyrs] which was modified several times, and in it a paragraph titled $O$ męczennikach $w$ Anglijej [On Martyrs in England]. Its most basic part consisted of - starting with the 1585 edition - the story of St Edmund Campion, St Ralph Sherwin and Alexander Briant's mission and martyrdom, which was a free adaptation of the narration contained in Concertatio Ecclesiae Catholicae in Anglia by John Fenn and John Gibson (1583). Skarga's interest in the figure of Campion was also reflected in the Polish translation of Rationes decem (1583) that he made at the request of King Stephen Báthory. It may be said that Rationes decem (also published in Latin in 1605) became one of the fundamental apologetic texts in Poland of the early-modern age, and St Edmund Campion, in a sense, became the patron of controversial theology, which would find its confirmation in the $18^{\text {th }}$ century adaptation of Nicholas Sanders and Edward Rishton's work De origine ac progressu schismatis Anglicani (1748) written by Jan Poszakowski.

Key words: Jesuit mission in England; St Edmund Campion; Robert Persons; James Bosgrave; Polish Jesuits; old-Polish translations; Rationes decem; De persecutione Anglicana; hagiography; The Lives of Saints; controversial theology; Piotr Skarga; Kasper Wilkowski.

Translated from Polish by Tadeusz Karłowicz

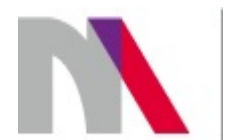

The preparation of the English version of Roczniki Humanistyczne and its publication in electronic databases was financed under contract no. 836/P-DUN/2018 from the resources of the Minister of Science and Higher Education for the popularization of science. 